\section{Professor Jacques Charvet - A Profile}

\section{IUGS Vice-President}

Born in Lyon, France, in 1941, Professor Jacques Charvet was a student at Ecole Normale Supérieure de Saint-Cloud (19611965) and at the same time studied geology at Paris University. After the "agrégation" (a competitive examination), he began his career at the University of Lille in 1965, where he was initially appointed as lecturer.

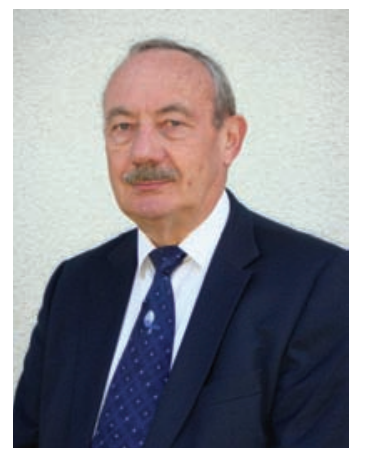

Besides his teaching duties, he started field research in former Yugoslavia (BosniaHerzegovina and Croatia), under the guidance of Prof. Paul Celet, to obtain the old style (long term) French Doctor's Degree. He studied the stratigraphy, paleogeography and structural evolution of the Dinarides along the transect Mostar-Sarajevo-Tuzla. This study led to the reconstruction of a geodynamic evolutionary model, from the Triassic rifting of the African margin to the last oceanic closure and collision with Europe, emphasizing the existence of a major Late Jurassic tectonic event, underlined by ophiolite obduction, before the Tertiary final piling of nappes.

After completing the doctoral degree, he completely changed his field of research and focused his interest on the geology of Japan, terrestrial and marine, in order to understand the modern geodynamic processes linked to subduction and to check the structural evolution of the Japanese Islands through time, especially in southern Japan, as they were assumed to be devoid of nappes and thus very different from the Alpine Belts. At almost the same time, he moved, as a Professor to the University of Orléans (1980).
The research in the west Pacific included cruises at sea, among them a diving campaign on the Nankai Trough within the FrenchJapanese KAIKO programme, participation in several ODP legs (87A and 128) and in a French cruise devoted to the Ryukyu Arc and Okinawa Trough. Such work led to a better understanding of the present building of accretionary prisms and opening of back-arc basins, essential for interpreting correctly the past subductions. This knowledge helped to decipher the geological evolution of Japan. $\mathrm{He}$ and his team of several PhD students suggested that this evolution was not simply due to a steady-state subduction since the Paleozoic (Pacific-type orogeny) but actually resulted from an alternation of subduction periods and collisional events responsible for the emplacement of conspicuous nappes, and tectonic windows, like in the Alpine chains. The new geodynamic model includes some major collisional events, for instance at the end of Permian and Late Jurassic.

After his experience in Japan, Charvet had the opportunity to study, with other colleagues and $\mathrm{PhD}$ students, the structural and geodynamic evolution of different types of mountain belts: the Central Range of Taiwan, the Espinhaço Range in Brazil (São Francisco craton), the Western US Cordillera (Klamath Mountains, California; Blue Mountains, Oregon and Idaho; NW Nevada). That research led to significant results such as the recognition of a pre-Brasiliano event in the Espinhaço Range and the determination of the pre-Carboniferous age for obduction of the famous Trinity ophiolite, in the Klamath Mountains. Meanwhile, he conducted field survey devoted to the structural control and the geodynamic environment of ore deposits: in the French Pyrénées, in the states of Santa Catarina and Minas Gerais (Brazil), and in the Iberian Pyrite Belt (Spain). In all these localities, the mineralization appears to be polyphase and tightly linked with the general tectonic evolution.

Finally, following the work in Japan, since the late 80 's he found interest and the opportunity to study the geology of China: firstly in SE China (Wuyi Shan and coastal area), and later in the Tianshan Belt in Central Asia (NW China) and in Inner Mongolia, participating in the understanding of the geodynamic evolution of the CAOB (Central Asian Orogenic Belt). Recently, he had the chance to look at the western extension of Tianshan in Kyrgyzstan. His most recent papers are all devoted to Chinese geology.

Prof. J. Charvet is the author of 140 articles in peer-reviewed journals.

In recognition of his work he has received the Gosselet prize of the Société des Sciences, des Arts et de l'Agriculture of Lille (1982), the Visquesnel prize of the Société géologique de France (1990), the Friendship Award for scientific cooperation of Jiangsu Province (1999), and the National Friendship Award of China (2002). He was nominated "Concurrent Professor" of the University of Nanjing. He is now emeritus professor at Orléans University.

He performed several administrative duties in the French geological community: President of the Société géologique du Nord (1980-1981), Vice-President of the Société géologique de France (1996-1997), member (since 1995) and President (2001-2004) of the French National Committee of Geology. He also has taken up numerous responsibilities in the Universities of Lille and Orléans, in different councils and commissions; among the most significant are, in the University of Orléans: the position of Vice-President in charge of research (1994-2002), the foundation and direction of the Graduate School of Sciences (1995-2002), and the foundation and direction (1985-1999) of a research team in tectonics and metallogeny affiliated with CNRS.

He was elected as IUGS Vice-President at the $33^{\text {rd }}$ IGC in Oslo, Norway for the period 2008-2012.

Address:

ISTO (Institut des Sciences de la Terre d'Orléans)

$1 \mathrm{~A}$ rue de la Férollerie

45100 Orléans

Tel : +33-2 38417007

Fax : +33-2 38636488

E-mail : jacques.charvet@univ-orleans.fr 